Article

\title{
Do Sustainable Procurement Practices Improve Organizational Performance?
}

\author{
Md. Mazharul Islam ${ }^{1, *}$ (D), Abalala Turki ${ }^{2}$, Md. Wahid Murad ${ }^{3}$ (D) and Azharul Karim ${ }^{4}$ \\ 1 Department of Finance, College of Business, King Abdulaziz University, Jeddah 21589, Saudi Arabia \\ 2 Department of Economics, Faculty of Economics and Administration, King Abdulaziz University, \\ Jeddah 21589, Saudi Arabia; tsabalala@kau.edu.sa \\ 3 UniSA College, University of South Australia, Adelaide, SA 5001, Australia; wahid.murad@unisa.edu.au \\ 4 Science and Engineering Faculty, Queensland University of Technology, Brisbane CBD, Brisbane, QLD 4001, \\ Australia; azharul.karim@qut.edu.au \\ * Correspondence: mazharulislam@yahoo.com or malislam@kau.edu.sa; Tel.: +966-568-543-711
}

Received: 23 October 2017; Accepted: 6 December 2017; Published: 13 December 2017

\begin{abstract}
This exploratory study investigates the impacts of sustainable procurement (SP) practices on organizational performance by using the established scales of SP practices and organizational performances, taking Saudi Arabia as a case country. Data used in the study was collected through a questionnaire survey from procurement directors and managers. Regression and multivariate-based path analysis was performed to assess the impacts of SP practices. From the preliminary results, a significant association between combined SP practices and organizations' financial performance was found. A mediational analysis was conducted to discover the direct and indirect effects of SP practices on financial performance. There was no evidence of a significant direct impact of the summary measures of SP practices on financial performance, while the indirect impact of SP practices via organizational nonfinancial performance on financial performance was found to be statistically significant. This study contributes to SP practice literature by developing a conceptual model for the outcomes of SP practices and establishing statistically significant relationships between SP practices, organizational financial performance, and mediating factors.
\end{abstract}

Keywords: sustainable procurement practices; organizational performance; private and public organizations; multivariate analysis; Saudi Arabia

\section{Introduction}

In response to the Sustainable Development World Summit [1], sustainable procurement (SP) has become an important agenda for governments seeking to demonstrate sustainable development [2]. Studies demonstrate that sustainable procurement practices can transform markets, save money, enhance financial viability, increase the competitiveness of eco-industries, protect natural resources, and foster job creation, which will in turn contribute to sustainable development. The strategic role of purchasing and supplying as a device for sustainable development has been strengthened recently. At the same time, environmental and social issues are increasingly becoming important in managing any business due to the increasing awareness of society and political leaders. These trends have contributed to SP practices, which are now considered an important aspect of corporate management that can empower organizations to advance their stated goals.

As a consequence, recent years have seen rapid growth globally in corporate and government organizations' interest in SP [2], ethical procurement [3], green procurement [4], lean practices [5] and e-procurement [6]. Academics and practitioners have been investigating how organizations and their suppliers affect the environment, society, and the economy $[7,8]$. Despite this increasing interest, evidence of the organizational performance in implementing SP practices is still lacking. 
Also, the impacts of SP practices on financial performance have not been widely investigated, especially in the case of Middle Eastern countries at large and Saudi Arabia in particular. Though the rapid expansion of research in the field of SP is admirable, there remains significant research gaps as highlighted above, and these therefore need to be addressed. An examination of the nature of research conducted between 2000 and 2017 revealed that a wide range of topics were covered, with better coverage of environmental/green topics than social purchasing and supply issues [9]. So far, there have been no research studies on the impacts of SP practices on organizational performance in the context of Middle Eastern countries. Moreover, views of sustainability are relative and differ across individuals, organizations, sectors, locations, and countries [7]. It has been shown that cultural and geographical differences may contribute to essentially different procurement and manufacturing strategies [10-12]. This study examines the relationships between SP practices and organizational performance in Saudi Arabia, which has a dominant culture of socialization strongly anchored in religion and steeped in tradition.

This article proceeds as follows: first, the relevant literature is reviewed and our hypotheses presented; second, our research method and analytical approach is presented; and third, our findings are presented, followed by our discussion and conclusions.

\section{Literature Review and Hypothesis Development}

In this section, six hypotheses are developed from a comprehensive literature review addressing definitions, SP practices, and relationships between SP practices and organizational financial and nonfinancial performances.

\subsection{Sustainable Procurement}

The concept of SP "is not simply about being 'green'. It is about purchasing with social and ethical responsibility; protecting environment balance buying procedures, carrying economically sound solutions; and noble business practice" [13]. Similarly, the definition developed by the United Kingdom government-commissioned Sustainable Procurement Taskforce [14] states that SP is "a process whereby organizations meet their needs for goods, services, works and utilities in a way that achieves value for money on a whole life basis in terms of generating benefits not only to the organization, but also to society and the economy, whilst minimizing damage to the environment". However, there is no common and accepted definition of SP as it varies across countries, organizations, and sectors. For the purpose of this study, the sustainable procurement definition that has been developed by the United Kingdom government-commissioned Sustainable Procurement Taskforce in 2006 is utilized. Since 2006, SP has emerged as a powerful way to contribute to the achievement of sustainable development goals through stimulating more sustainable consumption and production. SP policies focusing on environmental, social and economic issues can be integrated into the procurement activities.

\subsection{Sustainable Procurement Practices}

Sustainability knowledge relating to environment and society has increased in recent years, leading to pressure to change the ways in which organizations behave, particularly in their supply chain. Organizations need to adopt socially and environmentally responsible purchasing practices (SP practices) which have impacts on all aspects of the supply chain, including suppliers, employees, and customers [4], with aims to reduce the environmental and social impact of their own and their suppliers' activities, goods, and services [15]. Brammer and Walker [16] developed two new dimensions of sustainable procurement practices: buying locally and buying from small suppliers. In addressing SP practices, this study adopts the design and packaging of products, purchasing from small and local suppliers, products' potential for recycling or reuse, safety, labor rights, carbon reductions in the movement of products to facilities, operational excellence, product innovation, leadership, willingness of suppliers to commit to waste reduction goals, religion, and culture as dimensions of SP. 


\subsection{Sustainable Procurement Practices and Financial Performance}

Although a number of studies have been carried out, no consensus has been reached concerning the real benefits that SP practices provide to organizations. The benefits of implementing SP practices can be classified into financial and nonfinancial categories. Though earlier studies expressed doubt that green procurement strategies could pay off from an economic perspective [17], recent studies demonstrate that they could in fact result in improved financial performance [18].

Studies that have identified SP practices as key tools whereby organizations could yield a higher profitability have led to increasing attention to the topic in recent years [2,19]. For example, Chan and Wong [19] found that environmentally responsible purchasing can both increase organizational net income and reduce organizational overall costs, thus improve a firm's financial performance. Similarly, it has been reported that best-in-class procurement organizations have realized an incremental savings of up to $12 \%$ of cost [20]. Implementation of SP practices lowers the total costs of production through innovation [21]; and superior financial performance can be achieved using the excess discretionary slack resources to overcome the risk and unpredictability in adopting supply-side environmental practices [22]. Surajit [23] conducted a case study of an Indian manufacturing firm's procurement practices and concluded that SP practices improved the firm's financial performance through the increase in sales and market share. In addition, the findings of the study conducted by Laari [24] suggest that internal green supply chain management practices have the strongest effect on environmental performance and environmental collaboration with customers seems to be the most effective way to improve financial performance. By contrast, Murakami and Kimbara [25] did not find any significant relationship between green procurement and return on assets and sales, which leads a company's financial performance. Based on our review, we propose a null hypothesis:

Hypothesis 1 (H1). SP practices are positively related to organizational financial performance.

\subsection{Sustainable Procurement Practices and Nonfinancial Performance}

Our literature review revealed the significance of SP practices as a key competitive factor for organizations seeking global presence by encouraging foreign direct investment, and increasing global market share and an organization's performance has become an integral part of the SP system. A large number of studies have reported that there is a strong and positive relationship between sustainable procurement practices and company image, innovation, competitiveness, foreign direct investment, and strategic goals and targets [2,20,23,26]. For example, Surajit [23] reported that Indian manufacturing companies have achieved their strategic goals, target, and improved company image and competitiveness after implementing world-class procurement practices; while Yeow and Edler [27] stated that sustainable procurement can be best enabled by a systemic and service-oriented approach and by securing a "space" and certain flexibility to innovate. Therefore, we hypothesized the following:

Hypothesis 2 (H2). SP practices are positively related to local and international business performance.

The existing literature also reported that sustainable procurement is based on the belief that organizations can improve working environment (including health and safety), compliance, efficiency, transparency, and reduce the use of natural resources [2,26,28]. For example, Roos [26] has reported that Chile is a strong development performer, especially in terms of transparency, efficiency, and reuse of natural resources through the implementation of SP practices; and McMurray et al. [2] have stated that SP engagement has facilitated improvements in organizational working environments and conditions, efficiency, and transparency. In addition, Diab et al. [28] found a strong positive relationship between green procurement (GP) and quality and operational performance of Jordanian food industries. Kim and Chai [29] also provided empirical evidence that environmental practices and integration with suppliers are positively associated with performance. Therefore, we hypothesized the following: 
Hypothesis 3 (H3). SP practices are positively related to quality and operational performance.

According to Walker et al. [9], organizations must look across their entire supply chains to effectively address social and environmental impacts. Publications over the last decade show that SP has been seen as capable of delivering significant environmental benefits by practitioners, policy-makers, and academics, and SP practices have been seen as more powerful agents of change than any other corporate functions to reduce the environmental impact caused by business actions [30]. It has also been reported that SP practices significantly reduced environmental impact and improved social well-being in the UK. This finding is aligned with the conclusions of other studies which reported a positive relationship between the adoption of green SP practices and improvements in social and environmental performances [2,31]. For example, Guenther et al. [31] stated that green procurement implementation in Germany has reduced the sources of waste and promoted recycling and other environmental benefits; Adams et al. [32] found SP implementation is a key enabler that alleviated environmental issues, and provided social benefits. The OECD [33] also reported that sustainable procurement practiced in Switzerland resulted in high "environmental and social" standards throughout the product life cycle. Therefore, we hypothesized the following:

Hypothesis 4 (H4). There is a positive relationship between SP practices and social and environmental performance.

In addition, based on the overall literature discussed above, the following hypotheses were developed:

Hypothesis 5 (H5). Nonfinancial performance has a positive relationship to financial performance in an organization.

Hypothesis 6 (H6). Relationship between SP practices and financial performance is mediated by nonfinancial performance in an organization.

\subsection{Conceptual Framework}

From an extensive search in the available literature, we identified and analyzed relevant articles and developed a conceptual map illustrating the expected relationships and major hypotheses (Figure 1). The conceptual model shows impact pathways linking SP practices to local and international business performance, quality and organizational performance and social and environmental performance. Also, all these intermediary issues are thought to have potential impacts on financial performance. Financial performance is also perceived to be directly related to SP practices in an organization. The conceptual framework is a reflection of what we proposed to test in the above six hypotheses.

Based on an extensive search of relevant literature, we believe SP best practices mainly include three above dimensions in an organizational context of Saudi Arabia. However, ethical and supplier partnering related sub dimensions are also considered within those three dimensions. For example, within the sub dimensions of environmental purchasing, diversity, human rights, philanthropy and safety are considered. Also, within the organizational dimension of quality and operational performance we looked into the issue of adoption of information technology by the companies. In fact, adoption of technology by the companies in Saudi Arabia has been found to be instrumental in achieving their day-to-day organizational objectives, including procurement of resources and disbursement of goods and resources, both tangible and intangible. 


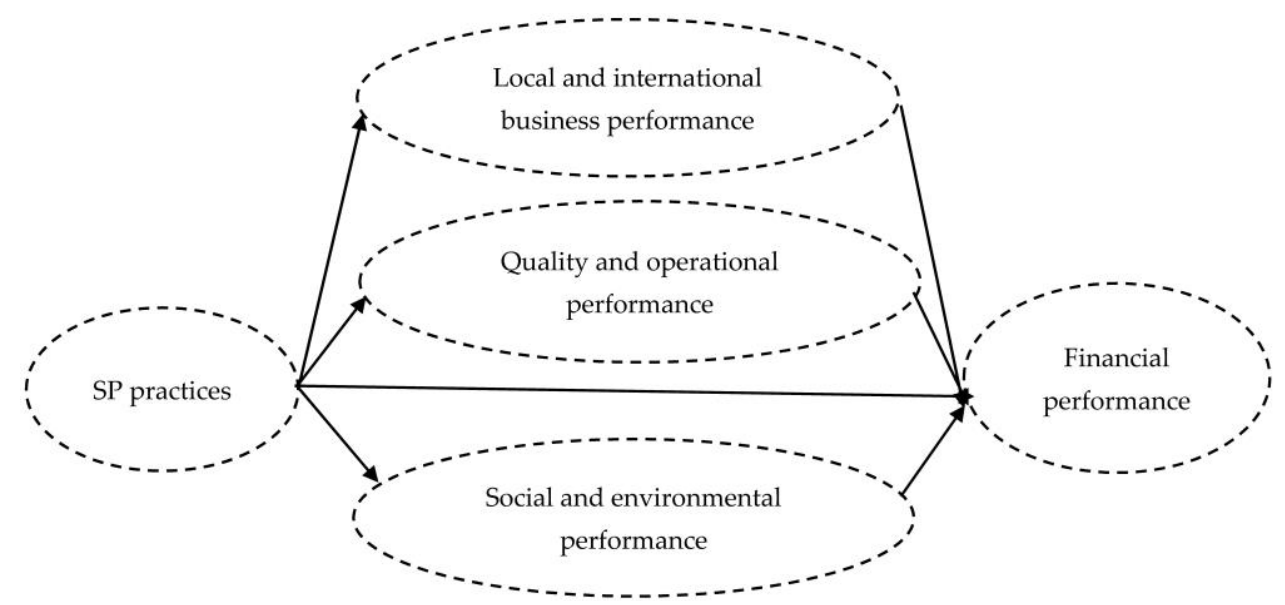

Figure 1. Conceptual representing the hypothesized relationships between sustainable procurement (SP) practices and organizational performances.

\section{Materials and Methods}

In this study, the research problems were first derived from the comprehensive analysis of the literature. A conceptual model was then developed and data was collected through a questionnaire survey to test the hypotheses and achieve the research objectives.

\subsection{Study Design}

This is a quantitative research study, in which we conducted a survey to test the hypotheses presented above. To achieve the objective of this study, a multivariate analysis was conducted together with the descriptive snapshot. Correlation and regression analysis was then conducted to explore the relationship between the combined practices (the average mean values of all practices) of SP and financial performance (the average mean values of all scales) and nonfinancial performance (the average mean values of all scales). In addition, we also conducted regression-based path analysis to explore whether nonfinancial performances act as a mediator between SP practices and organizational financial performance. This technique is similar to path analysis in structural equation modeling (SEM), except that observed variables instead of hypothetical latent variables are regressed. A regression approach was considered more appropriate than SEM due to the limited sample size in the current study. Essentially, regression-based path analysis involves estimating the partial coefficients in a path model like the one shown in Figure 1-that is, the extent to which predictor variables have direct and indirect influences (via other independent variables) on the dependent variable. The specific regression model we used took the following form:

$$
Y_{i}=\beta_{0}+\beta_{1} X_{j}+\beta_{2} Z_{j}+\varepsilon_{i j}
$$

where $Y_{i}$ stands for an organization's performance variables (four types of performances), $X_{j}$ is a vector of explanatory variables (six SP scales) which are expected to increase organizations' performance, and $Z_{j}$ is a vector of control variables (types of organization, types of ownership of the organization, education levels of the respondents, type of sectors, and length of time for working as procurement director/manager).

\subsection{Questionnaire, Sample Design, and Data Collection Procedure}

Based on the comprehensive literature review, the survey instruments were developed. After obtaining necessary ethical clearance, the first stage of the study was a pretest of the instrument. The questionnaire was pretested and validated by a focus group, which was comprised of two SP academic experts from King Abdulaziz University, Jeddah, one academic expert from Queensland 
University of Technology (QUT), Australia and two procurement directors/managers drawn from private organizations in Saudi Arabia. Based on the pretesting, some modifications were done to the questionnaire. For example, it was strongly suggested by an expert panel during the pilot study that we ought to add a social and environmental dimension of nonfinancial performance that related to engaging in SP practices. The pilot participants felt that social and environmental performance was a key part of a company's engagement in SP practices, because of the effects on local and international social development and global environmental problems.

The format was confirmed as being appropriate with language levels that were appropriate and understood, as the survey was conducted in English and Arabic by undertaking Triandis's [34] back-to-back translation approach. The final instrument was comprised of three sections in two pages. The first section covered the company's profile and the second section consisted of 16 items on SP practices and the third section consisted of 13 items on benefits (financial and nonfinancial) measured on a 1-5 Likert scale (5 represented strongly agree, most important, or strong improvement, whereas 1 represented strongly disagree, least important, or strong deterioration and 3 represented neutral, modest or fair) to assess the impact of implementation of SP practices on organizational performances. The nonfinancial performances (benefits) of the organization were generally covered by three major areas namely, local and international business performance, quality and operational performance, and social and environmental performance [35,36].

The revised questionnaire was handed over by fully trained research assistants to a systematic random sample of 400 procurement directors or managers employed in both public and private sector organizations across various fields (manufacturing, agriculture, construction, services, SMEs, and mining) and locations in Saudi Arabia. About 10 percent of returned responses were independently monitored and validated in real time by the project leader.

\subsection{Measure of the Constructs}

\subsubsection{SP Practices}

The purchasing and social responsibility (PSR) standard, which was developed by Carter and Jennings [4], was utilized in this study as a proxy measure of SP practices due to the lack of availability of a published validated measure. The PSR standard examined five purchasing components:

(1) Environment (sample question: currently our purchasing function uses a life-cycle analysis to evaluate the environmental friendliness of products and packaging);

(2) Diversity (sample question: currently our purchasing function has a minority/women-owned business enterprise supplier purchase program);

(3) Human rights (sample question: currently our purchasing function asks suppliers to pay a "living wage", which is greater than a country's or region's minimum wage);

(4) Philanthropy (sample question: currently our purchasing function donates to philanthropic organizations); and

(5) Safety (sample question: currently our purchasing function ensures that suppliers' locations are operated in a safe manner).

The PSR standards used in the study were shown to have acceptable internal consistency and reliability (Cronbach's alpha values for the scales ranged from 0.70 to 0.86 ) and evidence of content and construct validity [4].

\subsubsection{Organizational Performances}

There are several aspects [37] and several approaches [38] to measure organizational performance. We considered relevant aspects and approaches for this study. The measures of organizational performances are divided into two categories: financial and nonfinancial performance measures $[35,36,39,40]$. The performance standards were shown to have high reliability (Cronbach's 
alpha values ranged from 0.77 to 0.89 ) and content and construct validity as evidenced by convergent validity (factor loadings of respective measured items $>0.50$ ) and discriminant validity (AVE $>r^{2}$ ). Following the approach developed by Islam et al. [40], a 27-item nonfinancial performance standard and five-item financial performance standard were utilized as a proxy measure.

\section{Results}

\subsection{Profile of the Organizations}

The findings presented in Table 1 show that about $82 \%$ (164) of the organizations were fully Saudi-owned and $18 \%$ (36) of organizations were joint ventures between Saudi and foreign owners. Approximately $86 \%$ (172) of the organizations were private while $14 \%$ (28) were public organizations. Organization types were SMEs $36.5 \%$ (73), services $27.5 \%$ (55), manufacturing $23 \%$ (46), construction $10.5 \%$ (21), agriculture $2 \%(4)$, and mining $0.5 \%$ (1). The respondents' educational levels were $64.0 \%$ (128) graduates; $21.5 \%$ (43) of respondents held diploma degrees; $12 \%$ (24) of respondents' highest qualification was year 12 education, and only $2.5 \%$ (5) of respondents had postgraduate degrees.

Table 1. Descriptive snapshots of the data set.

\begin{tabular}{ccc}
\hline Questions & Elements & Number \& (\%) \\
\hline \multirow{2}{*}{ Type of ownerships } & Local & $164(82 \%)$ \\
& Joint ventures & $36(18 \%)$ \\
\hline \multirow{2}{*}{ Type of sectors } & Public & $28(14 \%)$ \\
& Private & $172(86 \%)$ \\
\hline \multirow{2}{*}{ Type of organizations } & Manufacturing & $46(23 \%)$ \\
& Service & $55(27.5 \%)$ \\
& Construction & $21(10.5 \%)$ \\
& SMEs & $73(36.5 \%)$ \\
& Agriculture & $4(2 \%)$ \\
& Mining & $1(0.5 \%)$ \\
\hline \multirow{2}{*}{ Education level of the respondents } & Year 12 & $24(12 \%)$ \\
& Diploma & $43(21.5 \%)$ \\
& Graduate & $128(64 \%)$ \\
& Master/PhD & $5(2.5 \%)$ \\
\hline
\end{tabular}

\subsection{SP Practices}

The 16 SP practice related items developed by Carter and Jennings [4] and Brammer and Walker [16] have factor loading above 0.50 and five extracted factors. The value of Cronbach's alpha as the measure of internal consistency was used to assess the reliability of all extracted factors. As all the Cronbach's alpha values $(\alpha)$ are above 0.82 , all the scales of SP practices are considered reliable measures [19]. The lowest $\alpha$ value was observed for purchasing from small and local firms (0.818) and the highest for philanthropy at 0.966 . The high level of $\alpha$ value for all the scales under this study indicates that the items were reliable and consistent and that each of the items was unique and not a repetition. This can be attributed to the fact that all the questionnaire items were carefully developed and further scrutinized by pilot study and by area experts. The validity of all the scales of SP practices were confirmed by convergent validity (factor loadings of respective measured items $>0.50$ ) and discriminant validity (AVE $>r^{2}$ ), as shown in Table 2 . 
Table 2. Rotated factor matrix, reliability, and validity statistics.

\begin{tabular}{|c|c|c|c|c|}
\hline Factors & Factor Loadings & Cronbach Apha $(\alpha)$ & $\mathrm{AVE}^{1}$ & $\left(r^{2}\right)^{2}$ \\
\hline \multicolumn{5}{|l|}{ Organizational Performance (4 Scales) } \\
\hline $\begin{array}{l}F_{1}=\text { Local and International Business Performance } \\
\text { (4 items)(External Benefits) } \\
\text { Meeting goals and targets } \\
\text { Improve organization's image (reputation) } \\
\text { Improve innovation and competitiveness } \\
\text { Encourage foreign investment }\end{array}$ & $\begin{array}{l}0.884 \\
0.808 \\
0.851 \\
0.718\end{array}$ & 0.710 & 0.667 & 0.170 \\
\hline $\begin{array}{l}F_{2}=\text { Quality and Operational Performance (5 items) } \\
\text { Improve working environment } \\
\text { Improve compliance } \\
\text { Improving efficiency and transparency } \\
\text { Improve working conditions: labour standard, health \& safety } \\
\text { Reduce use of natural resources }\end{array}$ & $\begin{array}{l}0.867 \\
0.854 \\
0.742 \\
0.635 \\
0.586\end{array}$ & 0.812 & 0.556 & 0.184 \\
\hline $\begin{array}{l}F_{3}=\text { Social and Environmental Performance }(2 \text { items }) \\
\text { Alleviation of global environmental problem } \\
\text { Alleviation of social problem in local and other parts of the world }\end{array}$ & $\begin{array}{l}0.927 \\
0.876 \\
\end{array}$ & 0.911 & 0.813 & 0.170 \\
\hline $\begin{array}{l}F_{4}=\text { Financial Performance }(2 \text { items }) \\
\text { Reduction of overall costs } \\
\text { Return on Asset (ROA) }\end{array}$ & $\begin{array}{l}0.77 \\
0.73\end{array}$ & 0.790 & 0.563 & 0.184 \\
\hline SP practices (5 Scales) & & & & \\
\hline $\begin{array}{l}F_{1}=\text { Environmental Purchasing } \\
\text { Uses a life-cycle analysis to evaluate the environmental friendliness } \\
\text { of products and packaging } \\
\text { Participates in the design of products for disassembly } \\
\text { Asks suppliers to commit to waste reduction goals } \\
\text { Participates in the design of products for recycling or reuse } \\
\text { Reduces packaging material }\end{array}$ & $\begin{array}{l}0.702 \\
0.734 \\
0.862 \\
0.878 \\
0.814\end{array}$ & 0.871 & 0.642 & 0.059 \\
\hline $\begin{array}{l}F_{2}=\text { Diversity } \\
\text { Purchase from minority and women owned business enterprise } \\
\text { (MWBE) suppliers } \\
\text { Has a formal minority and women owned business enterprise } \\
\text { (MWBE) supplier purchase program }\end{array}$ & 0.925 & 0.892 & 0.857 & 0.057 \\
\hline $\begin{array}{l}F_{3}=\text { Human rights } \\
\text { Visits suppliers' plants to ensure that they are not using } \\
\text { sweatshop labour } \\
\text { Ensures that suppliers comply with child labour laws } \\
\text { Asks suppliers to pay a 'living wage' greater than a country's or } \\
\text { region's minimum wage }\end{array}$ & $\begin{array}{l}0.940 \\
0.912 \\
0.932\end{array}$ & 0.948 & 0.861 & 0.056 \\
\hline $\begin{array}{l}F_{4}=\text { Philanthropy } \\
\text { Donates to philanthropic organizations } \\
\text { Volunteers at local charities }\end{array}$ & $\begin{array}{l}0.958 \\
0.949\end{array}$ & 0.966 & 0.909 & 0.057 \\
\hline $\begin{array}{l}F_{5}=\text { Safety } \\
\text { Ensures the safe, incoming movement of product to our facilities } \\
\text { Ensures that suppliers' location are operated in a safe manner }\end{array}$ & $\begin{array}{l}0.956 \\
0.950\end{array}$ & 0.955 & 0.908 & 0.041 \\
\hline $\begin{array}{l}F_{5}=\text { Purchases from small and local suppliers } \\
\text { Purchases from small suppliers } \\
\text { Purchases from local suppliers }\end{array}$ & $\begin{array}{l}0.904 \\
0.916\end{array}$ & 0.818 & 0.828 & 0.059 \\
\hline
\end{tabular}

${ }^{1} \mathrm{AVE}=\Sigma \mathrm{X}_{i}{ }^{2} / n$ (number of items $i=1, \ldots, n ; \mathrm{X}_{\mathrm{i}}$, factor loading); ${ }^{2} r^{2}$, the highest squared correlation between the factor of interest and the remaining factors.

\subsection{Descriptive Statistics}

Among the sample organizations, the four most disregarded dimensions of SP were found to be "purchase from minority and women-owned business enterprises" (1.94), "the presence of a formal program for making purchases from minority and women-owned business enterprises" (1.96), "participates in the design of products for recycling or reuse" (2.61), and "participates in the design of products for recycling or reuse" (2.69). This finding suggests that "donates to philanthropic organizations" and "volunteers at/for local charities" are the most commonly embedded SP dimensions instead of environmental practices.

In order to determine the SP variation between private and public organizations and between local and joint-venture organizations, an independent samples $t$-test was conducted. The results in Table 3 reveal that, in the engagement of SP activities, the private organizations were well ahead of the public organizations. The mean score of three dimensions of SP, "asks suppliers to commit to waste reduction goals", "donates to philanthropic organizations", and "purchases from small suppliers", 
was significantly greater $(p \leq 0.05)$ for the private organizations than the public organizations, while the remainder of SP practices were statistically insignificant.

The independent samples $t$-test results also identified that overall the joint-venture organizations were much better position than the local organizations in the engagement of SP activities. Joint venture organizations were significantly ahead $(p \leq 0.05)$ of local organizations in adopting only two dimensions of SP practices, "asks suppliers to commit to waste reduction goals" and "donates to philanthropic organizations", while the remainder of SP practices were statistically insignificant.

Table 3. Organizational variation in items of SP practice in terms of mean value.

\begin{tabular}{|c|c|c|c|c|c|c|}
\hline SP Practices & LOw (1) & JOw (2) & PriO (3) & PubO (4) & Overall Mean & Sig. Diff. Groups \\
\hline $\begin{array}{l}\text { Uses a life-cycle analysis to evaluate the } \\
\text { environmental friendliness of products } \\
\text { and packaging. }\end{array}$ & 2.18 & 3.40 & 3.11 & 2.46 & 2.79 & None \\
\hline $\begin{array}{l}\text { Asks suppliers to commit to waste } \\
\text { reduction goals. }\end{array}$ & 3.30 & 3.80 & 3.79 & 3.30 & 3.55 & $(3-4) * *(1-2) *$ \\
\hline Reduces packaging material & 3.54 & 3.59 & 3.94 & 3.19 & 3.57 & None \\
\hline $\begin{array}{l}\text { Participates in the design of products } \\
\text { for disassembly. }\end{array}$ & 2.59 & 2.63 & 2.68 & 2.54 & 2.61 & None \\
\hline $\begin{array}{l}\text { Participates in the design of products for } \\
\text { recycling or reuse. }\end{array}$ & 2.69 & 2.68 & 2.87 & 2.50 & 2.69 & None \\
\hline $\begin{array}{l}\text { Has a formal minority and women owned } \\
\text { business enterprise (MWBE) supplier } \\
\text { purchase program. }\end{array}$ & 1.85 & 2.12 & 2.23 & 1.75 & 1.99 & $(3-4) *$ \\
\hline Purchase from MWBE define suppliers. & 1.85 & 2.03 & 1.88 & 2.00 & 1.94 & None \\
\hline $\begin{array}{l}\text { Ensures the safe incoming movement of } \\
\text { product to our facilities. }\end{array}$ & 3.52 & 3.55 & 3.59 & 3.48 & 3.54 & None \\
\hline $\begin{array}{l}\text { Ensures that suppliers' location are operated } \\
\text { in a safe manner. }\end{array}$ & 3.55 & 3.56 & 3.84 & 3.28 & 3.56 & None \\
\hline $\begin{array}{l}\text { Visits suppliers' plants to ensure that they } \\
\text { are not using sweatshop labor. }\end{array}$ & 2.78 & 2.93 & 2.90 & 2.81 & 2.86 & None \\
\hline $\begin{array}{l}\text { Ensures that suppliers comply with child } \\
\text { labor laws. }\end{array}$ & 2.67 & 2.78 & 2.89 & 2.57 & 2.73 & None \\
\hline $\begin{array}{l}\text { Asks suppliers to pay a 'living wage' greater } \\
\text { than the country's or region's } \\
\text { minimum wage. }\end{array}$ & 2.74 & 2.87 & 2.82 & 2.79 & 2.81 & None \\
\hline Volunteers at/for local charities. & 3.60 & 3.84 & 3.87 & 3.56 & 3.72 & None \\
\hline Donates to philanthropic organizations. & 3.40 & 3.91 & 3.91 & 3.41 & 3.66 & $(3-4)^{* *}(1-2)^{*}$ \\
\hline Purchases from local suppliers. & 3.25 & 3.95 & 3.41 & 3.79 & 3.60 & $(3-4)^{*}$ \\
\hline Purchases from small suppliers. & 3.43 & 3.85 & 3.86 & 3.41 & 3.64 & $(3-4)^{*}$ \\
\hline
\end{tabular}

In order to test Hypotheses 1-4, a correlation analysis was performed on the SP practices of organizational nonfinancial and financial performance scales. One-tailed significance tests were performed due to the limited sample size and expected positive correlations; the results are shown in Table 4. The results in Table 4 reveal that three out of six SP practices scales were significantly and positively associated with both financial and nonfinancial organizational performance, with the strongest relationship between environmental purchasing, as a practice of SP, and organizational quality and operational performance $(r=0.372)$. The remaining three SP scales were positively but insignificantly related to performance scales. In addition, we carried out correlations among the summary measure (created by averaging scores for the scales) of SP practices and organizational performance scales, the results of which are shown in Table 5. The correlation analysis showed that all scales of organizational performance were significantly and positively related to overall SP practices, with the strongest relationship between "social and environmental performance" $(r=0.395)$ as a facet of organizational performance, and SP practices. Overall, this result provided acceptable evidence that all facets of SP practices impacted on organizational nonfinancial performance as well as financial performance, with all correlations being in the predicted direction. 
Table 4. Inter-correlation among sustainable procurement practices scales and organizational performances.

\begin{tabular}{ccccc}
\hline SP Practices 5 Scales $\backslash$ Performance Scales & LIBP & QOP & SEP & FP \\
\hline Environmental purchasing practices & $0.137^{*}$ & $0.372^{* *}$ & $0.279^{* *}$ & $0.200^{* *}$ \\
Diversity practices & $0.181^{*}$ & 0.134 & 0.076 & 0.036 \\
Human rights practices & $0.146^{*}$ & 0.054 & $0.151^{*}$ & 0.054 \\
Philanthropy practices & $0.319^{* *}$ & $0.222^{* *}$ & $0.254^{* *}$ & $0.223^{* *}$ \\
Safety practices & $0.074^{* *}$ & $0.048^{* *}$ & $0.243^{* *}$ & $0.126^{* *}$ \\
Purchasing from small and local firms practices & $0.201^{* *}$ & $0.192^{* *}$ & $0.288^{* *}$ & $0.240^{* *}$ \\
\hline \multicolumn{2}{c}{ Notes: ${ }^{* *} p \leq 0.01 *^{*} p \leq 0.05}$. & &
\end{tabular}

Notes: ${ }^{* *} p \leq 0.01 ; * p \leq 0.05$.

Table 5. Inter-correlation among overall SP practice, and organizational financial and non-financial performances.

\begin{tabular}{cc}
\hline Performance Scales $\backslash$ Overall SP Practices & SP Practices \\
\hline Local and International Business Performance & $0.286^{* *}$ \\
Quality and Operation Performance & $0.264^{* *}$ \\
Social and Environmental Performance & $0.395^{* *}$ \\
Financial Performance & $0.258^{* *}$ \\
\hline \multicolumn{2}{c}{ Notes: ${ }^{* *} p \leq 0.01}$.
\end{tabular}

Tables 6 and 7 identify the variation in the benefits of the adoption of SP dimensions across the sectors, types, and ownerships of the organizations. The procurement directors/managers of the construction sector registered significantly higher levels of SP practices compared to other sectors. For example, the mean scores for the construction sector are greater than that of other sectors on all benefits. Particularly, this sector scored significantly greater on social and environmental performance $(p \leq 0.05)$, and financial performance benefits $(p \leq 0.05)$.

Table 6. Effects of SP practices on performances classified by type of company.

\begin{tabular}{cccccccc}
\hline Benefits & Manu. (1) & Serv. (2) & Cons. (3) & SMEs (4) & Agri. (5) & Min. (6) & Sig. Diff. \\
\cline { 2 - 6 } & Mean & Mean & Mean & Mean & Mean & Mean & \\
\hline $\begin{array}{c}\text { Local and International } \\
\text { Business Performance }\end{array}$ & 4.18 & 4.14 & 4.27 & 4.23 & 4.25 & 3.75 & None \\
\hline $\begin{array}{c}\text { Quality and Operation } \\
\text { Performance }\end{array}$ & 3.79 & 3.76 & 3.79 & 3.77 & 3.75 & 3.00 & None \\
\hline $\begin{array}{c}\text { Social and Environmental } \\
\text { Performance }\end{array}$ & 4.60 & 4.59 & 4.72 & 4.52 & 4.70 & 4.20 & $(3-4)^{*}$ \\
\hline Financial Performance & 3.83 & 4.00 & 4.24 & 3.70 & 4.07 & 4.00 & $(3-4)^{* *}$ \\
\hline & & Notes: ${ }^{* *} p \leq 0.01 ; * 0.05$. & & &
\end{tabular}

The results in Table 7 indicate that joint ventures compared to local organizations and private compared to public organizations had both higher financial and nonfinancial benefits from the implementation of SP practices but the differences were statistically insignificant. Possible explanation of this result could be that the nature, culture and practices of purchasing of joint ventures differ from local organization's practices and similarly public sector purchasing practices differ from private sector practices. In addition, a possible explanation could also be that private organizations and joint ventures are profit driven whilst public organizations are not necessarily for-profit. Moreover, public organizations are generally more politically constrained than private organizations and most private organizations have significantly different organizational objectives than their public counterparts. Organizational structure and level of commitment associated with public and private sectors could be another potential explanation. 
Table 7. Effects of SP practices on performances classified by type of ownership and sectors.

\begin{tabular}{ccccccc}
\hline Benefits & Local (1) & Joint Ventures (2) & Sig. Diff. & Public (1) & Private (2) & \multirow{2}{*}{ Sig. Diff. } \\
\cline { 2 - 3 } & Mean & Mean & & Mean & Mean & \\
\hline $\begin{array}{c}\text { Local and International } \\
\text { Business Performance }\end{array}$ & 4.18 & 4.24 & none & 4.12 & 4.21 & None \\
\hline $\begin{array}{c}\text { Quality and Operation } \\
\text { Performance }\end{array}$ & 4.57 & 4.63 & none & 4.57 & 4.64 & None \\
\hline $\begin{array}{c}\text { Social and Environmental } \\
\text { Performance }\end{array}$ & 3.75 & 3.88 & none & 3.73 & 3.78 & None \\
\hline Financial Performance & 3.87 & 3.92 & none & 3.83 & 4.14 & None \\
\hline
\end{tabular}

For further analysis of $\mathrm{H} 1, \mathrm{H} 2, \mathrm{H} 3, \mathrm{H} 4$, and $\mathrm{H} 5$, multiple regression analyses were conducted by using a total nonfinancial performance score and financial performance score (created by averaging scores for the all scales). For regression analysis, the F-test and adjusted $R^{2}$ value confirmed that regression is meaningful in the sense that the dependent variable is related to each specified explanatory variable. The correlation matrix of the independent variables was studied to identify the occurrence of multicollinearity. The correlation matrix also ensured that the Pearson's $r$ between each pair of independent variables did not exceed 0.80. It means that the independent variables are not too highly related to each other. Moreover, for collinearity diagnostics, the eigenvalues of the explanatory variables were studied by factoring the scaled (so that diagonal elements are 1's), uncentred cross products matrix of the independent variables. Eigenvalues provide an indication of how many distinct dimensions are there among the independent variables. Since in the present model, several eigenvalues of the explanatory variables are not close to 0 , thus the variables are proved to be not intercorrelated and the matrix is said to be efficient-conditioned.

The $R^{2}$ statistic for the first regression showed that more than 41 percent of the variance in nonfinancial performance was predictable from all of the SP practices scales, while $R^{2}$ for the second regression showed that more than 35 percent of the variance in financial performance was predictable from all of the scales of SP practices. These results show a good fit for these data. The $F$-test showed a highly significant result $(p \leq 0.01)$, which implies that the variables in the models, taken together, are significant predictors of organization's nonfinancial as well as financial performance.

Table 8 provides results of the regression analyses, which reveal that, controlling for types of sector, types of ownership, types of organization, education, and duration with the organization in the model, three of the six SP practices dimensions was important predictors of organizational nonfinancial performance as well as financial performance. The SP practices dimension "purchases from small and local suppliers" was the most important and significant SP practice that positively effects of organizational nonfinancial performance $(\beta=0.246, p \leq 0.01)$ as well as financial performance ( $\beta=0.207, p \leq 0.01)$, followed by the SP practices dimensions "environmental purchasing" and "philanthropy" with nonfinancial performance $(\beta=0.237, p \leq 0.01 ; \beta=0.204, p \leq 0.01)$ and "philanthropy" and "safety" with financial performance $(\beta=0.200, p \leq 0.01 ; \beta=0.164, p \leq 0.05)$. The rest of the SP practices dimensions did not have strong influence on organizational performance. These findings confirm that the impact of SP practices is not restricted to the nonfinancial and financial performance of an organization.

Table 9 shows that all dimensions of organizational nonfinancial performance were significant predictors of organizational financial performance. The nonfinancial performance dimension "quality and operation performance" was the most strongly related to organizational financial performance ( $\beta=0.277, p \leq 0.01)$, followed by "social and environmental performance" $(\beta=0.235, p \leq 0.01)$ and "local and international business performance" ( $\beta=0.192, p \leq 0.05)$. Indeed, the path from these scales to organizational financial performance was not significantly different from zero. The organizational nonfinancial performance dimensions accounted for 33 percent of the variance in organizational financial performance. Therefore, taken as a whole, the present study confirms that the impact 
of nonfinancial performance dimensions on financial performance of an organization is positive and significant.

Table 8. Results of the regression analysis for SP practice scales with organizational performance scales.

\begin{tabular}{ccc}
\hline \hline Independent Variable & \multirow{2}{*}{ Non-Financial Performance $(\beta)$} & Financial Performance $(\boldsymbol{\beta})$ \\
\hline Environmental Purchasing & $0.237^{* *}$ & $0.098^{\mathrm{NS}}$ \\
Diversity & $0.066^{\mathrm{NS}}$ & $-0.009^{\mathrm{NS}}$ \\
Human rights & $-0.035^{\mathrm{NS}}$ & $-0.051^{\mathrm{NS}}$ \\
Philanthropy & $0.204^{* *}$ & $0.200^{* *}$ \\
Safety & $0.113^{\mathrm{NS}}$ & $0.164^{*}$ \\
Purchases from small and local suppliers & $0.246^{* *}$ & $0.207^{* *}$ \\
Number of observation & 200 & $200^{2}$ \\
$R^{2}$ & 0.411 & $0.351^{* *}$ \\
$F$ value $(6)^{\text {a }}$ & $4.837^{* *}$ & $3.588^{* *}$ \\
\hline
\end{tabular}

Notes: ${ }^{* *} p \leq 0.01 ;{ }^{*} p \leq 0.05 ;{ }^{\mathrm{NS}}=$ not significant; ${ }^{\text {a }}$ Indicates degree of freedom.

Table 9. Results of the regression analysis for non-financial performance scales with financial performance scales.

\begin{tabular}{cc}
\hline Independent Variable & Financial Performance $(\beta)$ \\
\hline Dependent Variables & $0.192^{*}$ \\
Lual and International Business Performance & $0.277^{* *}$ \\
Social and Environmental Performance & $0.235^{* *}$ \\
Number of observation & 200 \\
$R^{2}$ & 0.326 \\
$F$ value $(3)^{\text {a }}$ & $6.910^{* *}$ \\
\hline Notes: ${ }^{* *} p \leq 0.01 ;{ }^{*} p \leq 0.05^{\text {a }}$ Indicates degree of freedom.
\end{tabular}

In order to test H6- “the relationship between SP practices and financial performance is mediated by non-financial performance in an organization"-we carried out the regression-based path analysis described by Hair et al. [41] as appropriate for such cases. Basically, regression-based path analysis involves the estimation of the partial coefficients in a path model. In other words, it determined the extent to which predictor variables have direct and indirect influences on the dependent variable. This estimation provided a test of whether the relationship between SP practices and financial performance is mediated by the organizational nonfinancial performance.

A regression analysis was performed using the summary measures of SP practices, organizational nonfinancial performance, and organizational financial performance to examine whether SP practices predicted organizational nonfinancial and financial performances. First, the scale of SP practices was regressed onto organizations' nonfinancial performance; this model was significant $(F=4.12$, $p \leq 0.01$ ) (Table 10). Multiple regression analysis found that when controlling for types of sector, types of ownership, types of organization, education, and duration with the organization in the model, the index of overall SP practices was significantly and positively related to nonfinancial performance ( $\beta=0.417, p \leq 0.01$; see Table 10), explaining 25.3 percent of the variance in the nonfinancial performance construct. Second, the scale of SP practices was regressed onto organizational financial performance; this model was also significant $(F=3.71, p \leq 0.01$; see Table 11). The result of this regression analysis found that, controlling for types of sector, types of ownership, types of organization, respondents' educational level, and respondents' duration with the organization in the model, SP practices were significantly and positively related to organizational financial performance $(\beta=0.258$, $p \leq 0.01$ ), explaining 23.2 percent of the variance in the organizational financial performance construct.

Finally, both SP practices and organizational nonfinancial performance were simultaneously regressed onto organizational financial performance. The results in Table 12 show that nonfinancial performance was a significant predictor $(p \leq 0.01)$ of financial performance, while combined practices of SP was not. Only three of six SP practices dimensions showed evidence of mediation, using tests of indirect effects. The indirect effects from "environmental purchasing," "philanthropy," and 
"purchasing from local and small firms" factors were statistically significant. The partial effect ( $\beta=0.463)$ of nonfinancial performance on financial performance was significant $(p \leq 0.01)$, while the coefficient $(\beta=0.417$ ) for the direct effect of SP practices on organizational nonfinancial performance was significant $(p \leq 0.01)$. The direct effect of the summary measures of SP practices (taken together six scales of SP practices) on financial performance was not significant $(\beta=0.065 ; p=0.342)$, while the indirect effect of SP practices via organizational nonfinancial performance on financial performance was statistically significant $(\beta=0.193$ ). Significant indirect effects indicate that organizational nonfinancial performance did significantly mediate the relationship between SP practices and organizational financial performance.

Table 10. Regression analysis for prediction of non-financial performance ${ }^{\text {a }}$ by overall SP practices $(n=200)$.

\begin{tabular}{|c|c|c|c|c|}
\hline Model & Independent Variable & $\mathbf{R}^{2}$ & B & $\mathbf{F}$ \\
\hline 1 & Overall SP practices & 0.253 & $0.417^{* *}$ & $4.12^{* *}$ \\
\hline
\end{tabular}

Table 11. Regression analysis for prediction of financial performance ${ }^{\mathrm{a}}$ by overall SP practices $(n=200)$.

\begin{tabular}{|c|c|c|c|c|}
\hline Model & Independent Variable & $\mathbf{R}^{2}$ & B & $\mathbf{F}$ \\
\hline 2 & Overall SP practices & 0.232 & $0.258 * *$ & $3.71^{* *}$ \\
\hline
\end{tabular}

Table 12. Regression analysis for prediction of financial performance ${ }^{\text {a }}$ by non-financial performance and overall SP practices $(n=200)$.

\begin{tabular}{cccc}
\hline Model & Independent Variable & B & F \\
\hline \multirow{2}{*}{3} & Overall SP practices & $0.065^{\text {NS }}$ & $6.49^{* *}$ \\
& Non-financial performance & $0.463^{* *}$ & $6.49^{* *}$ \\
\hline
\end{tabular}

Notes: ${ }^{a}$ Dependent variable; ${ }^{* *} p \leq 0.01 ;{ }^{\text {NS }}$ indicates not significant.

\section{Discussion}

The results show that few dimensions of sustainable procurement practices are embedded in both public and private organizations in Saudi Arabia. The private organizations were significantly ahead of public organizations in terms of engagement in SP activities, which is consistent with the findings of the current studies conducted to date elsewhere [2,16,42]. In contrast, public organizations had a significantly higher mean than private organizations for only one dimension of SP: "purchases from local suppliers". A possible reason to prioritize the purchase of goods and services from a local supplier could be motivated by political will to support Saudi Arabia's recent diversification objectives, which will lead to economic growth, job creation, and economic diversification. Both public and private organizations adopted the same dimensions of SP practices on a priority basis and benefited financially and non-financially. However, interestingly our findings reported that there is no significant difference between private and public organizations in terms of organizational performance.

Construction is found to be one of the most polluting sectors in Saudi Arabia as it suffers from many resource wastes [43]. The positive thing is that this industry is aware about it and is keen to improve the social, economic, and environmental indicators of sustainability [44]. In order progress towards this objective, the industry needs to implement sustainable construction practices and thus eliminate or minimize the negative impacts that it has on the environment [45]. In addition, construction is the largest category of expenditure in Saudi Arabia, with the current expenditure rising to more than $\$ 120$ billion a year [46]. The Kingdom's construction industry encompasses $15 \%$ of its 
workforce [43]. The boom in the construction industry reflects the rapid growth in the Kingdom's domestic economy [47].

The most interesting finding in this study is generally the very weak and insignificant positive relationship between SP practices and financial performance that contrasts with the findings of the majority of studies conducted to date $[17,19,20,22,23]$. The direct relationship of SP practices with financial performance appears to have been reported without any concrete evidence. Therefore, in this study a mediational analysis was conducted to discover the indirect effects of SP practices on financial performance. With respect to the mediational analyses, the study shows that three dimensions of performance, "environmental purchasing," "philanthropy," and "purchasing from local and small firms," are involved in the mediational process. The finding of partial mediation suggests that other variables might also be involved in the mediational process. The findings of this study are consistent with research that indicates that, after controlling for demographic variables $[2,9,23,26,28,48]$ and theoretical models for sustainable or green procurement practices are positively and significantly associated with reduced use of natural resources; increased product quality; improved company image, innovation, competitiveness, and foreign direct investment; meeting strategic goals and targets; and improved working environment, compliance, efficiency, and transparency, and working conditions. Our findings provide further evidence that improvement in an organization's internal quality and operational process, innovativeness, efficiency, and transparency, social responsiveness, and environmental issues are highly influenced by SP practices.

Therefore, SP practices may assist organizations in remaining competitive in a rapidly changing marketplace where consumers are becoming more sensitive to sustainability issues and are demanding deeper transparency into the products they buy. In addition, legal obligations force organizations to be mindful of the impact of their decisions and ensure that they do not cause harm to suppliers and workers. However, provided below is Table 13 in which the hypothesis testing results have been summarized.

Table 13. Summary results of hypothesis testing.

\begin{tabular}{clcc}
\hline Hyp. & Null Hypothesized Relationship & $+/-$ & Rej./Don't $\mathbf{H}_{\mathbf{o}}$ \\
\hline H1 & SP practices are positively related to organizational financial performance & + & Don't reject \\
\hline H2 & SP practices are positively related to local and international business performance. & + & Don't reject \\
\hline H3 & SP practices are positively related to quality and operational performance. & + & Don't reject \\
\hline H4 & $\begin{array}{l}\text { There is a positive relationship between SP practices and social and } \\
\text { environmental performance }\end{array}$ & + & Don't reject \\
\hline H5 & Nonfinancial performance has a positive relationship to financial performance & + & Don't reject \\
\hline H6 & SP practices and financial performance is mediated by nonfinancial performance & + & Don't reject \\
\hline
\end{tabular}

\section{Conclusions}

The concept of sustainable procurement is receiving an increasing level of attention at both the local and global levels, as well as by academics and industry practitioners. Impacts and benefits of SP practices have been an important research agenda since 2002, as it has been considered a vehicle for value creation of an organization [20] through transforming markets, increasing competitiveness of eco-industries, saving money, protecting natural resources, and fostering job creation, which will in turn contribute to sustainable development. According to the literature, the majority of studies reported a direct positive relationship between SP practices and an organization's financial performance; however, most studies are descriptive in nature and therefore a statistically strong and reliable relationship cannot be established. This study examines SP practices within organizations and the relationships between SP practices and organizational performance, taking Saudi Arabia as a case location. The key contribution of the paper is its evidence concerning the effects of SP practices on financial and nonfinancial performance of the organization. In fact, SP practices definitely helped organizations to achieve better financial benefits through improvement of organization's 
internal quality and operational process, innovativeness, efficiency, transparency, and social and environmental responsiveness.

The findings of this study have significant research implications. Most studies reported direct financial benefit from adopting SP practices, ignoring the internal mediating factors. The approach to GP holds important implications for managers, by directing limited resources towards projects which intersect both environmental performance and economic performance [49]. This study shows that SP practices contribute to organizational financial performance through mediating effects of nonfinancial performance processes. Thus, we have contributed a new insight to the growing body of research addressing implementation of SP practices in both private and public sector contexts. However, as the analysis is cross-sectional, it provides a snapshot of SP practices at one point in time and therefore we cannot yet determine whether levels of organizational financial and nonfinancial performances are increasing or decreasing over time because of SP practices.

The findings in this study provide several recommendations for Saudi Arabian policy-makers. Study suggests that the stakeholders involved with the entire procurement process require engaging in and acting together in order to move the sustainable procurement agenda forward. The government is best placed to deal with the obstacles of finance, regulation, and policy. Individual procurement directors, senior managers, other professional and educational bodies could raise the level of sustainable development awareness across Saudi Arabia by introducing simple and clear sustainable procurement guidelines, developing awareness-raising sustainable procurement programs including the generation of wider publicity in the form of conferences, workshops, books, media coverage, and journals.

Acknowledgments: This project was funded by the Deanship of Scientific Research (DSR) at King Abdulaziz University, Jeddah, under grant no. G-91/120/34. The authors, therefore, acknowledge with thanks DSR for technical and financial support.

Author Contributions: Md. Mazharul Islam the team leader and designed the research instruments in consultation with other authors and conducted the research as an expertise in the areas of SP, supply chain, culture and performance measurement. Turki Abalala and Md. Wahid Murad analyzed data and Azharul Karim contributed to the analysis of the results and drafting of the manuscript.

Conflicts of Interest: The authors declare no conflict of interest.

\section{References}

1. WSSD. Plan of Implementation of the World Summit on Sustainable Development; United Nations: New York, NY, USA, 2002.

2. McMurray, A.J.; Islam, M.M.; Siwar, C.; Fien, J. SP in the Malaysian Organizations: Practices, Barriers and Opportunities. J. Purch. Supply Manag. 2014, 20, 195-207. [CrossRef]

3. Wild, N.; Li, Z. Ethical procurement strategies for international aid non-government organizations. Supply Chain Manag. Int. J. 2011, 16, 110-127. [CrossRef]

4. Carter, C.R.; Jennings, M. The role of purchasing in corporate social responsibility: A structural equation analysis. J. Bus. Logist. 2004, 25, 145-186. [CrossRef]

5. Karim, M.A.; Arif-Uz-Zaman, K. A methodology for effective implementation of lean strategies and its performance evaluation in manufacturing organizations. Bus. Process Manag. J. 2013, 19, 169-196. [CrossRef]

6. Angeles, R.; Ravi, N. Business-to business e-procurement: Success factors and challenges to implementation. Supply Chain Manag. Int. J. 2007, 12, 104-115. [CrossRef]

7. Walker, H.; Phillips, W. Sustainable procurement: Emerging issues. J. Public Procure. 2009, 2, 41-61. [CrossRef]

8. Walton, S.V.; Handfield, R.B.; Melnyk, S.A. The Green Supply Chain: Integrating Suppliers into Environmental Management Processes. Int. J. Purch. Mater. Manag. 1998, 34, 2-12. [CrossRef]

9. Walker, H.; Alexander, A.; Touboulic, A. An overview of sustainable public procurement research. In Balancing Social, Environmental and Economic Considerations in Procurement; United Nations: New York, NY, USA, 2012; pp. 8-13.

10. Karim, M.A.; Smith, A.J.R.; Halgamuge, S.; Islam, M.M. A comparative study of manufacturing practices and performance variables. Int. J. Prod. Econ. 2008, 112, 841-859. [CrossRef] 
11. Karim, M.A.; Smith, A.J.R.; Halgamuge, S. Empirical relationships between some manufacturing practices and performance. Int. J. Prod. Res. 2008, 46, 3583-3613. [CrossRef]

12. Samson, D.; Ford, S. Manufacturing practices and performance: Comparisons between Australia and New Zealand. Int. J. Prod. Econ. 2000, 65, 243-255. [CrossRef]

13. Muthugala, S.; Nayagam, N. Incorporating the triple bottom line in public procurement. In Balancing Social, Environmental and Economic Considerations in Procurement; United Nations: New York, NY, USA, 2012; pp. 30-33.

14. DEFRA. Procuring the Future-The SP Task Force National Action Plan; Department for Environment, Food and Rural Affairs: London, UK, 2006.

15. Avery, S. Lean, but Not Mean, Rockwell Collins Excels. Purchasing 2005, 134, 26-32.

16. Brammer, S.; Walker, H. Sustainable procurement practice in the public sector: An international comparative study. Int. J. Oper. Prod. Manag. 2011, 31, 452-476. [CrossRef]

17. Carter, J.R.; Maltz, A.; Yan, T.; Maltz, E. How procurement managers view low cost countries and geographies: A perceptual mapping approach. Int. J. Phys. Distrib. Logist. Manag. 2008, 38, 224-243. [CrossRef]

18. Pullman, M.E.; Maloni, M.J.; Carter, C.R. Food for thought: Social versus environmental sustainability practices and performance outcomes. J. Supply Chain Manag. 2009, 45, 38-54. [CrossRef]

19. Chan, T.Y.; Wong, C.W. The consumption side of sustainable fashion supply chain: Understanding fashion consumer eco-fashion consumption decision. J. Fash. Mark. Manag. 2012, 16, 193-215. [CrossRef]

20. Bobis, V.; Staniszewski, J. Making the Case for Sustainable 'Green' Procurement. IBM Global Business Services 2009. Available online: http://www-935.ibm.com/services/us/gbs/bus/pdf/sustainable_ procurement_bobis_staniszewski.pdf (accessed on 16 March 2017).

21. Porter, M.; van der Linde, C. Green and competitive: Ending the stalemate. Harv. Bus. Rev. 1995, 73, $120-134$.

22. Menguc, B.; Auh, S.; Ozanne, L. The interactive effect of internal and external factors on a proactive environmental strategy and its influence on a firm's performance. J. Bus. Ethics 2010, 94, 279-298. [CrossRef]

23. Surajit, B. World Class Procurement Practices and Its Impact on Firm Performance: A Selected Case Study of an Indian Manufacturing Firm. J. Supply Chain Manag. Syst. 2012, 1, $27-39$.

24. Leary, S. Green Supply Chain Management Practices and Firm Performance: Evidence from Finland; Painosalama Oy: Turku, Finland, 2016.

25. Murakami, K.; Kimbara, T. Does CSR Enhance the Transfer of Environmental Practices to Overseas Subsidiaries? J. Bus. Adm. Res. 2015, 4, 1-8. [CrossRef]

26. Roos, R. Prerequisites for sustainable public procurement in developing countries. In Balancing Social, Environmental and Economic Considerations in Procurement; United Nations: New York, NY, USA, 2012; pp. 38-42.

27. Yeow, J.; Edler, J. Innovation Procurement as Projects. J. Public Procure. 2012, 12, 472-504.

28. Diab, S.M.; AL-Bourini, F.A.; Abu-Rumman, A.H. The Impact of Green Supply Chain Management Practices on Organizational Performance: A Study of Jordanian Food Industries. J. Manag. Sustain. 2015, 5, 149-157. [CrossRef]

29. Kim, M.; Chai, S. Implementing Environmental Practices for Accomplishing Sustainable Green Supply Chain Management. Sustainability 2017, 9, 1192. [CrossRef]

30. Ho, L.W.P.; Dickinson, N.M.; Chan, G.Y.S. Green procurement in the Asian public sector and the Hong Kong private sector. Nat. Resour. Forum 2010, 34, 24-38. [CrossRef]

31. Guenther, E.; Scheibe, L.; Farkavcova, V.G. The Hurdles analysis as an instrument for improving sustainable stewardship. Manag. Res. Rev. 2010, 33, 340-356. [CrossRef]

32. Adams, C.A.; Muir, S.; Hoque, Z. Measurement of sustainability performance in the public sector. Sustain. Acc. Manag. Policy J. 2014, 5, 46-67. [CrossRef]

33. OECD. Promoting Sustainable Consumption: Good Practices in OECD Countries; OECD Publications: Paris, France, 2008.

34. Triandis, H.C. Essentials of studying culture. In Handbook of Intercultural Training; Landis, D., Brislin, R., Eds.; Pergamon: New York, NY, USA, 1983; pp. 82-118.

35. Abdel-Maksoud, A.; Dugdale, D.; Luther, R. Non-financial performance measurement in manufacturing companies. Br. Acc. Rev. 2005, 37, 261-297. [CrossRef]

36. Psomas, E.; Kafetzopoulos, D. Performance measures of ISO 9001 certified and noncertified manufacturing companies. Benchmark. Int. J. 2014, 21, 756-774. [CrossRef] 
37. Da Cruz, N.; Marques, R. Revisiting the determinants of local government performance. OMEGA Int. J. Manag. Sci. 2014, 44, 91-103. [CrossRef]

38. Simoes, P.; Marques, R. On the economic performance of the waste sector.A literature review. J. Environ. Manag. 2012, 106, 40-47.

39. Gijsel, P.V. The Importance of Non-Financial Performance Measures during the Economic Crisis. Master's Thesis, Tilburg University, Tilburg, The Netherlands, 2012.

40. Islam, M.M.; Habes, E.; Karim, A.; Syed Agil, S.O. Quality Certification and Company Performance-The Newly Developed Country Experience. J. Bus. Econ. Manag. 2015, 17, 628-644. [CrossRef]

41. Hair, J.F., Jr.; Anderson, R.E.; Tatham, R.L.; Black, W.C. Multivariate Data Analysis, 5th ed.; Prentice-Hall: Englewood Cliffs, NJ, USA, 2006.

42. Hasselbalch, J.; Costa, N.; Blecken, A. Examining the relationship between the barriers and Current practices of SP: A survey of UN organizations. J. Public Procure. 2014, 14, 293-326.

43. Sarhan, J.G.; Xia, B.; Fawzia, S.; Karim, M.A. Lean construction implementation in the Saudi Arabian construction industry. Constr. Econ. Build. 2017, 17, 46-69. [CrossRef]

44. Ortiz-Rodríguez, O.; García-Cáceres, R. Assessing sustainability within the construction industry by means of a composite indicator. DYNA 2013, 80, 15-24.

45. Chan, H.Y.; Lee, C.T.B.; Lee, C.J. Sustainability in the Construction Industry in Malaysia: The Challenges and Breakthroughs. Int. J. Soc. Behav. Edu. Econ. Bus. Ind. Eng. 2014, 8, 1218-1222.

46. Alrashed, I.; Alrashed, A.; Taj, S.; Phillips, M.; Kantamaneni, K. Risk Assessment for Construction Projects in Saudi Arabia. Res. J. Manag. Sci. 2014, 3, 1-6.

47. Deloitte. Construction-The Economic Barometer for the Region. Deloitte GCC Powers of Construction 2015. Available online: https:/ /www2.deloitte.com/content/dam/Deloitte/xe/Documents/realestate/construction/ gccpowersofconstruction/me_construction_gccpoc2015_publication.pdf (accessed on 21 December 2016).

48. Gavronski, I.; Klassen, R.D.; Vachon, S.; Nascimento, L.F.M. A Resource Based View of Green Supply Management. Transp. Res. 2011, 47, 872-885. [CrossRef]

49. Appolloni, A.; Sun, H.; Fu, J.; Li, X. Green Procurement in the Private Sector: A State of the Art Review between 1996 and 2013. J. Clean. Prod. 2014, 85, 122-133. [CrossRef] 